\title{
Envisioning South-South relations in the fields of environmental change and migration in the Pacific Islands - past, present and futures
}

\author{
Eberhard Weber
}

Correspondence: weber_e@usp.ac.fj School of Geography, Earth Science and Environment, The University of the South Pacific, Laucala Campus, Suva, Fiji

\begin{abstract}
Climate change poses severe threats to developing countries. Scientists predict entire states (e.g. Kiribati, Marshall Islands, Tuvalu, and Maldives) will become inhabitable. People living in these states have to resettle to other countries. Media and politicians warn that climate change will trigger migration flows in dimensions unknown to date. It is feared that millions from developing countries overwhelm developed societies and increase pressures on anyway ailing social support systems destabilizing societies and becoming a potential source of conflict.

Inhabitants of Pacific Islands ${ }^{a}$ have been mobile since the islands were first settled not longer than 3,500 years ago. Since then people moved around, expanded their reach, and traded with neighbouring tribes (and later countries). With the event of European powers in the $15^{\text {th }}$ century independent mobility became restricted after the beginning of the $19^{\text {th }}$ century. From the second half of the $19^{\text {th }}$ century movements of people predominately served economic interests of colonial powers, in particular a huge colonial appetite for labour. After independence emigration from Pacific Island countries continued to serve economic interest of metropolitan countries at the rim of the Pacific Ocean, which are able to direct migration flows according to their economic requirements.

If climate change resettlements become necessary in big numbers then Pacific Islanders do not want to become climate change refugees. To include environmental reasons in refugee conventions is not what Pacific Islanders want. They want to migrate in dignity, if it becomes unavoidable to leave their homes. There are good reasons to solve the challenges within Pacific Island societies and do not depend too much on metropolitan neighbours at the rim of the Pacific such as Australia, New Zealand and the USA. To rise to the challenge requires enhanced Pan-Pacific Island solidarity and South-South cooperation. This then would result in a reduction of dependencies. For metropolitan powers still much can be done in supporting capacity building in Pacific Island countries and helping the economies to proposer so that climate change migrants easier can be absorbed by expanding labour markets in Pacific Island countries.
\end{abstract}

\section{Springer}

(c) 2015 Weber; licensee Springer. This is an Open Access article distributed under the terms of the Creative Commons Attribution License (http://creativecommons.org/licenses/by/4.0), which permits unrestricted use, distribution, and reproduction in any medium, provided the original work is properly credited. 


\section{Introduction}

\section{Setting the challenges}

Climate Change has become one of the most pressing challenges of the $21^{\text {st }}$ century. For many years it has been seen from a perspective of mitigation: what can be done to prevent climate change from happening? Today's major concerns are: how can societies adjust, adapt to or at least cope with the impacts arising from climate change? In this discourse the question is, if moving away is a suitable adaptation strategy, or an acknowledgement that adaptation has failed.

In the past mobility played an outstanding role in the lives of Pacific Islanders. After the first had arrived some 3,500 years ago they then moved around freely. Later, colonial powers in the request for increasing labour shifted hundreds of thousands of people within the Pacific Island region. When supply of labourers within Pacific Islands faded they brought migrant workers from outside. Once Pacific Island countries became independent the mobility of its people did not abate; many more moved to countries at the rim of the Pacific.

Today the threat of climate change, sea-level rise and the risk of becoming inhabitable are real issues for many Pacific Islands. New motivations to go elsewhere appear on the horizon; yet there are little ideas how resettlement can be managed, if and once required. The paper thus is a beginning to envision how to avoid that climate change migrants become refugees. Migrant receiving countries do not wish to be flooded by huge waves of refugees putting strain on their social, economic and political systems. At the same time no migrant prefers to be a refugee; they all wish to be welcome wherever they have to turn to when their time at home runs out. All wish to be able to support themselves and their families through the skills they have acquired. No one wishes to live in uncertainty, without proper means of livelihoods and threatened to be sent away or punished just because it wasn't possible to stay in the countries they came from.

\section{The Pacific Island region}

The Pacific Ocean covers more than 165 million square kilometres extending to about a third of the surface of the Earth. With this it is the biggest geographical entity on Planet Earth. The Pacific Islands consists of 20,000 - 30,000 islands located south of the Tropic of Cancer (Ridgell 2006). As a rough indication the region is sub-divided into Micronesia, Melanesia and Polynesia, and Timor Leste, which lies further west to the actual Pacific islands. The islands of the first sub-division are mainly situated north of the equator and those of the second and third category as well as Timor Leste are situated in the southern hemisphere (Figure 1).

All except one (Tonga ${ }^{b}$ ) had been colonies of foreign powers. Compared to the Americas and Asia colonialism started rather late and for most Pacific Islands the colonial period didn't last even 100 years. The first to become independent was Samoa in 1962 and the last Timor Leste where a civil war after a referendum in 1999 delayed formal independence from Indonesia until 2002.

Today most islands in the region belong to 15 independent states. Some islands, namely those belonging to American Samoa (USA), French Polynesia (France), Tokelau (New Zealand), Wallis \& Futuna (France), Guam (USA), Northern Mariana Islands (USA), and New Caledonia (France) are governed by a metropolitan power. Two Pacific ACP countries (Cook Islands and Niue) are in a free association with New Zealand. This includes New 


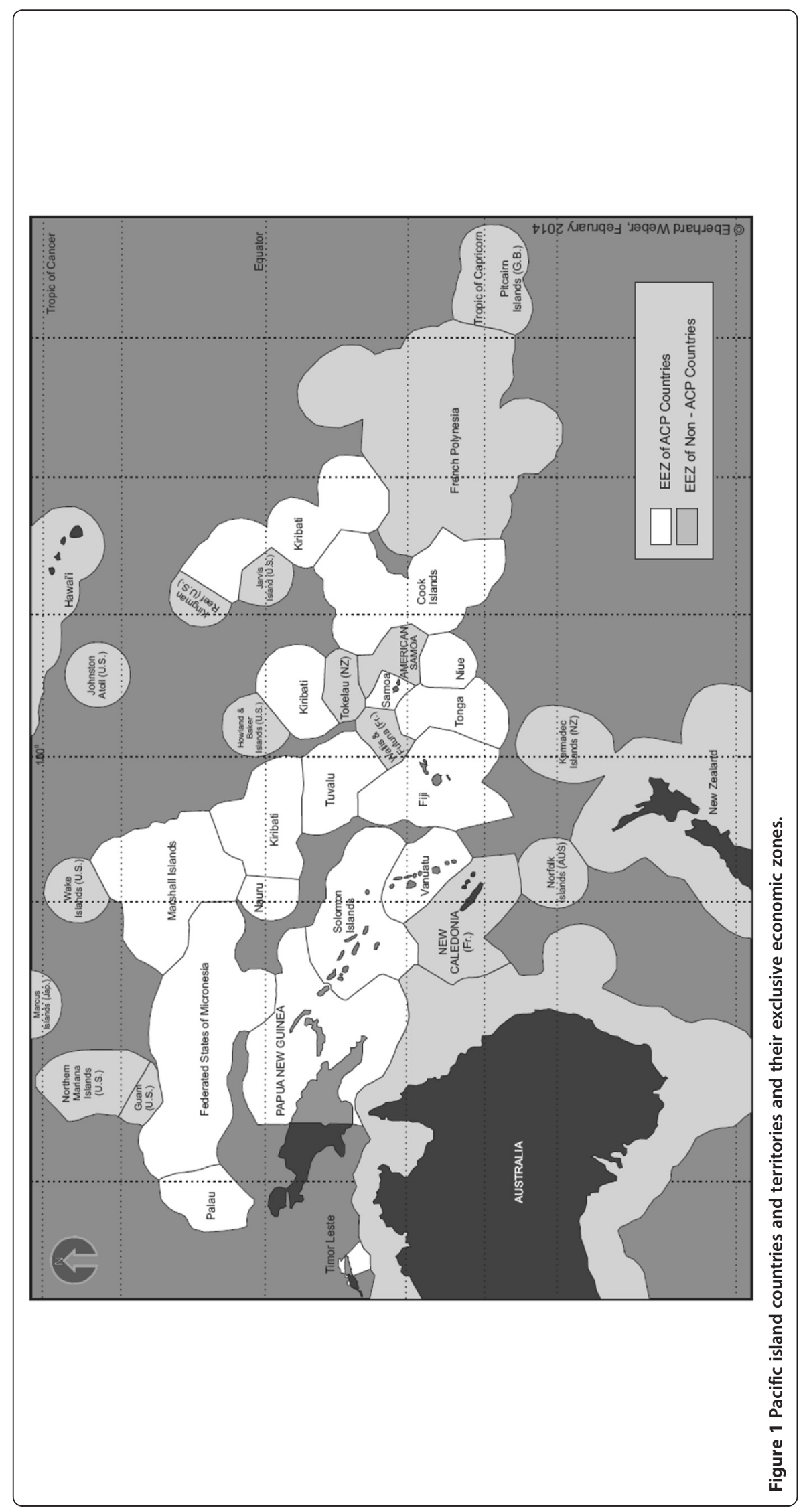


Zealand citizenship. Three Pacific ACP countries (Federated States of Micronesia, the Marshall Islands, and Palau) form a Compact of Free Association (COFA) with the USA. The citizens of these countries are free to live and work in the United States (Hills 1984).

Pacific Island countries and territories (incl. Timor Leste) comprise a total land area of a bit more than $565,000 \mathrm{~km}^{2}$ (Table 1). With their combined land areas they are roughly as big as Kenya. Papua New Guinea, the world's second biggest island next to Greenland, alone has more than 80 percent leaving the remaining 14 states and seven territories with a bit more than $100,000 \mathrm{~km}^{2}$, about the size of South Korea.

On the other hand the water body around the islands is tremendous: the combined Exclusive Economic Zone (EEZ) of all 15 Pacific Island countries and territories is almost 25 million $\mathrm{km}^{2}$. With this they cover an area considerably bigger than Russia, the world's largest country and almost three times the land area of China. Distances within the Pacific Island region are huge and transportation costs, both for people as well as goods, are expensive, especially as a result of rising costs for fossil fuels.

Pacific Islanders have been amongst the most mobile peoples over centuries. Take the tiny country of Niue, which today has a population of not even 1,500 and where another 6,000 live mainly in New Zealand. Or the people of the Cook Islands: some 15,000 of them live at home, whilst more than the same number live around the Pacific Rim, mainly in New Zealand (Campbell and Bedford 2014). Also other countries, where no dual citizenship with one of the metropolitan countries in their vicinity exists, have meaningful sections of their population outside their territories. Samoa, with a population at home of around 190,000, has another 120,000 people living overseas, mainly in New Zealand (World Bank 2011). Similarly, Tonga with a bit more than 100,000 people back home and roughly 50,000 outside (World Bank 2011). Even Fiji, a country that until recently was not perceived as an important source of migrants, has experienced emigration of around 120,000 citizens since the coups of 1987. In total more than 180,000 Fijians live outside their country (World Bank 2011). This is a huge number, considering that the country in 2014 had a population of less than 900,000.

\section{The four stages of mobility in Pacific Island countries}

The Pacific Islands were first settled by humans from East Asia, who came to the Pacific Islands in several phases. The first arrived some 40,000 years ago in what today is called New Guinea. They spread to the Bismarck Archipelago some 7,000 years later and arrived in what are the Solomon Islands today some 29,000 years ago. These islands belong to Near Oceania (Matisoo-Smith and Robins 2004). More than 20,000 years later Remote Oceania was settled from West to East starting from the Reef / Santa Cruz group in the Solomon Islands through Vanuatu, Fiji, Samoa and Tonga. After a pause of 500 -1,000 years Polynesians then settled the rest of the Polynesian Triangle spreading northwards to Hawaii, and southwards to New Zealand (Matisoo-Smith and Robins 2004: 9167).

With the arrival of Europeans in the Pacific Ocean a second stage started. In the early $16^{\text {th }}$ century the Pacific Oceans was little more than a seemingly endless body of water between the Spanish colonies in Asia and the Americas. During this time many islands were added to European knowledge, their locations drawn into the maps of the Pacific Ocean. It took until the start of the $19^{\text {th }}$ century before the islands first slowly and then since the mid- $19^{\text {th }}$ century more quickly were economically integrated into a colonial world system. 


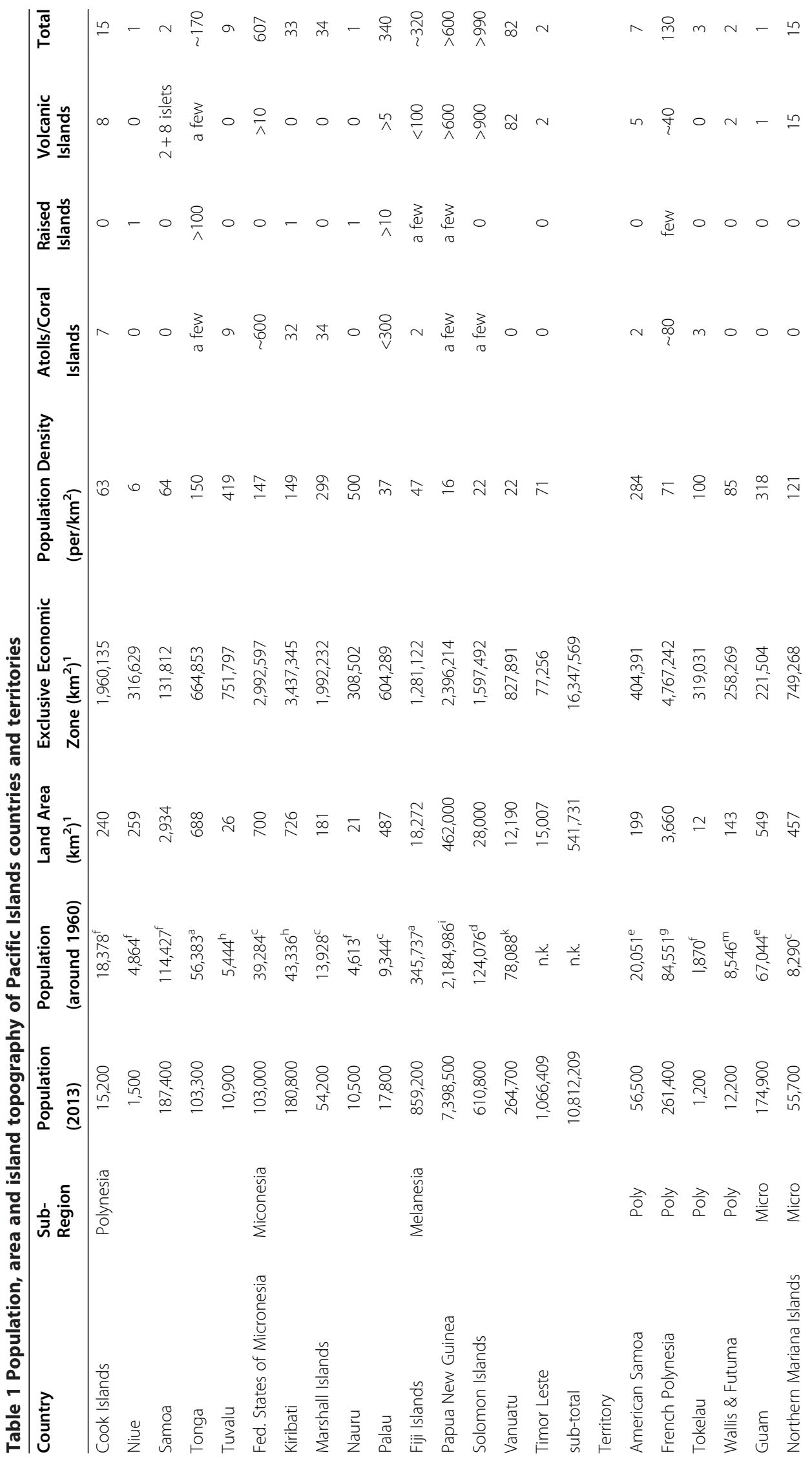




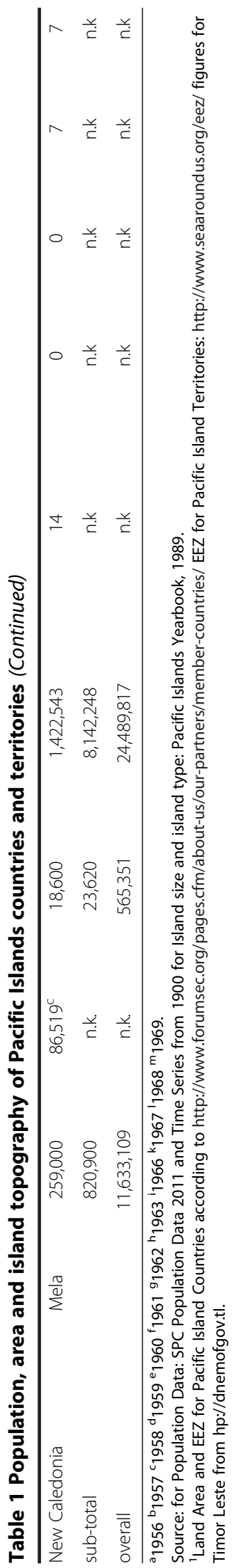


With the event of colonial rule movements within the Pacific suddenly became subordinated to external interests. Munro (1990: xxxix) estimates that the 'head-count', which is conservative and limited in its own way, enumerated almost one million Pacific Islanders and a further half million Asians who have been involved in the Pacific labour trade between the 1860s and 1939 (Figure 2).

Some exotic products like sandalwood (Shineberg 1967), sea-cucumber (Beche-de-mer; Ward 1972) caught the attention of European traders, castaways and adventurers and became important commodities for European trade with China. Once these exotic resources had been depleted colonial plantation agricultural for copra, cotton and sugar cane, to name the most important, provided an economic base for an increasing number of European settlers arriving in the bigger islands. To operate these plantations a big number of cheap indentured (contract) labourers was required.

In a few islands colonial plantations were competing with mining activities, for investment, but more importantly for labour. Very early nickel mining had been taken up in New Caledonia (1860s). Phosphate mining in Banaba (Ocean Island, today Kiribati), Nauru, Makatea (today French Polynesia), and Angaur (today Palau) starting at the early $20^{\text {th }}$ century. This brought many Pacific Islanders, but also labourers from Asia to these phosphate islands (Firth 1978).

Labour mobility in the mid- $19^{\text {th }}$ century led to a distinct demographic reconfiguration of many Pacific Island societies. Today they have meaningful sections from other Pacific societies, and meaningful Asian population segments.

In the second half of the nineteenth century some 60,000 Pacific Islanders were taken to Australia by black-birding ships to work in Queensland's sugar plantations (Flanagan et al. 2003). Around 10,000 were still living in Australia when the country achieved independence in 1901. Most of them were repatriated between 1906 and 1908 as a result of the White Australia Policy. Some 7,500 Pacific Islanders (called Kanakas) working on plantations in Queensland were deported, and entry into Australia was prohibited for Pacific Islanders after 1904 (Jupp 2007).

The third stage happened parallel to the second, but is different in a number of aspects: colonial powers resettled populations of entire islands within their colonial empire. Such resettlements happened to the people of Banaba (today Kiribati), who were brought to Rabi Islands (today Fiji) in 1945, Gilbert Islanders (today Kiribati) who were brought in 1938 to the Phoenix Islands, and then in the 1950s to the Western Province of today's Solomon Islands (Campbell 2014). This form of migration seems to resemble best what people often think of when they speak of resettlement of islands as a result of climate change: to evacuate the population of entire islands and bring them - as a group - to their new home.

The fourth stage started towards the end of colonial rule and continues into the years of independence. When in the 1950s and 1960s in Germany Gastarbeiter (guest workers) and migrants from Mexico into the USA supported the economic miracle of the Post War era also in Australia and New Zealand guest workers were needed in rapidly expanding economies (Ward 1989). A substantive number of skilled migrants came from Pacific Island countries, where highly skilled professionals were rather scarce. It meant a huge loss for sending countries when many of those few professionals left for greener pastures. At this time all Pacific Island countries were still colonies of European powers, Australia, New Zealand and the USA. Later when most of the countries had 


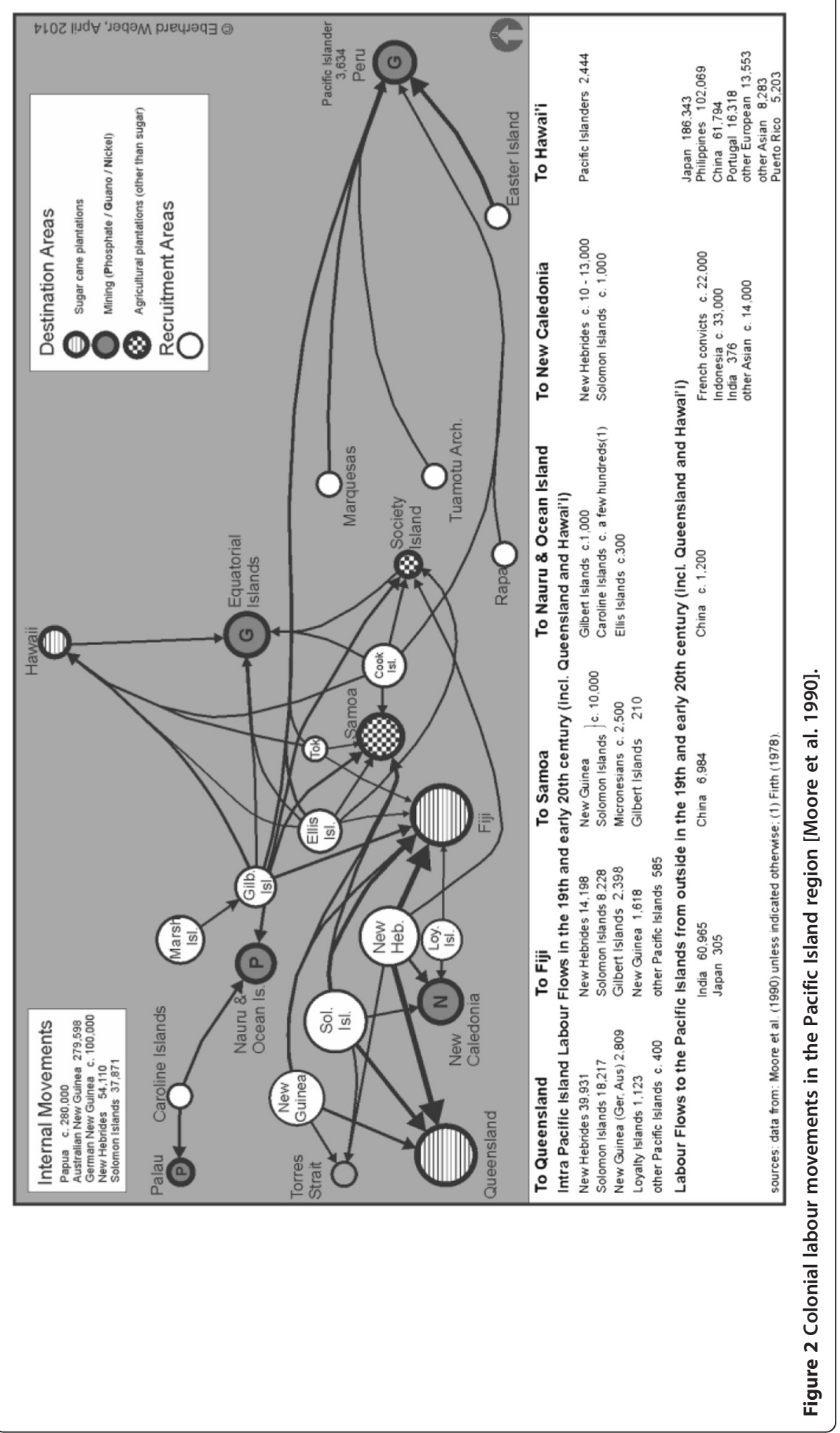


achieved independence recruitment of Pacific Islanders continued. Even attempts were made to liberalize immigration policies. New Zealand e.g. granted free entry to Pacific Islanders in 1986 but the program was discontinued the very same year as too many immigrants arrived (Goss and Lindquist 2000: 393).

\section{Analysis of labour markets in Pacific Island ACP countries}

Labour migration from and to Pacific Island countries reflect on their labour markets requirements, their need to recruit skilled labour from outside, and their ability to provide labour to other Pacific Island countries.

Economies of Pacific Island countries are very little diversified. Generally the formal sector is tiny, and it often consists of a dominating public sector (Table 2). Most wholesale businesses are part of the formal sector, while retail businesses are often semiformal or informal (Voigt-Graf 2008). They might require licenses to operate, but other requirements for the formal sector like social security provisions, formal entry requirements etc. are either not necessary or not implemented. Only a few Pacific Island countries have a meaningful modern manufacturing sector concentrating mainly on food processing (incl. alcoholic and non-alcoholic beverages), furniture, textiles and construction materials. The production of consumer electronics (television, computer, fridges, washing machine, etc.), cars and other motor vehicles, and capital goods is virtually non-existent in any Pacific Island country.

In all Pacific Island countries semi-subsistence agriculture and other rural and urban informal sectors play a dominant role. Formal sector employment is lowest in Melanesian countries and Timor Leste where the informal sector consists of around 75 percent (Fiji) to 94 percent (Papua New Guinea) of the workforce. In Micronesia the informal sector is between 65 percent (Marshall Islands) and 85 percent (Kiribati) while the corresponding figures for Polynesia are between 19 percent (Cook Islands) and 37 percent (Samoa) (Table 2; Booth et al. 2006, World Bank 2006).

Every year a number of young people wish to enter the workforce which is much bigger than jobs in the formal sector are available. Data gaps make it difficult to exactly quantify the number of missing formal employment. Alone in PNG year by year the annual net addition to the labour market is almost 160,000; in Fiji around 19,000 people join the labour market in a year (Table 2). For the entire Pacific Island region a very rough estimate is well above 200,000 - a lot if one considers that the formal economy in Pacific Island countries employs not much more than 500,000 (World Bank 2006).

Many Pacific Island countries have started to scale down their public sectors. Chand (2006) highlights that the role of the public sector is more or less restricted to create an enabling environment for the expansion of private sector activities. In some Pacific Island countries tourism has become a major economic sector, but so far the potentials are not yet fully utilized. Direct employment in resorts, hotels, restaurants, and transportation as well as spill-over effects to other economic sectors is seen by governments as a very promising outlook for the future.

\section{Policies and agreements that affect skilled labour mobility}

Removing obstacles to the movement of people (as well as goods and services) is increasingly considered a way of contributing to economic development through meeting identified labour shortages, transferring skills, and increasing remittances (ADB 2008). 


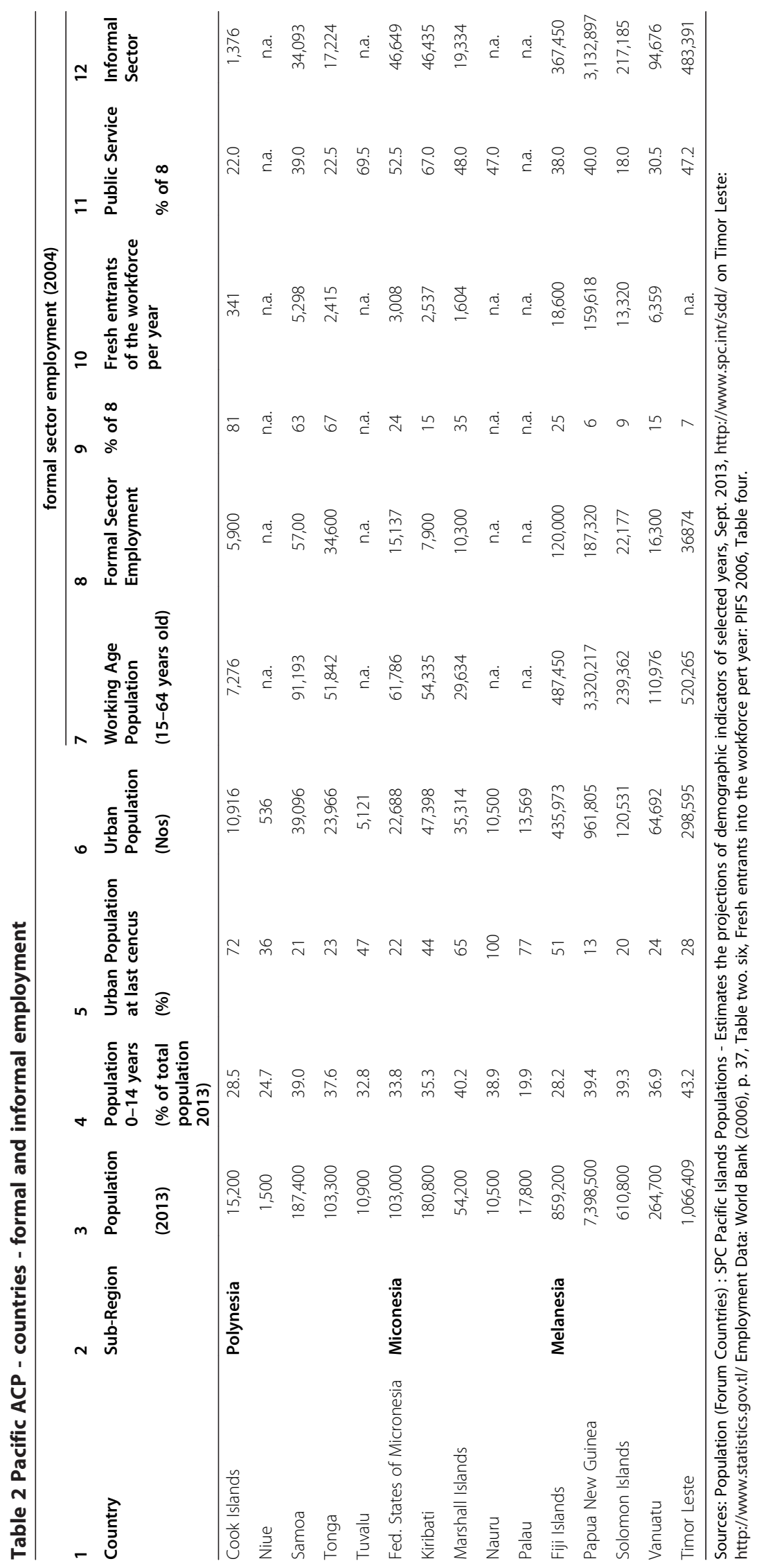


Pacific Island countries greatly vary in their access to international migration opportunities for work purposes. Some have fairly open access to working opportunities abroad due to special bilateral agreements (e.g. between New Zealand and certain Polynesian states) or some states in the north-western Pacific which have Compact of Free Association (COFA) status with the USA (Keitner and Michael 2003). People in other Pacific Island countries are more restricted in their by the immigration policies of destination countries (ACP-Observatory on Migration 2012; see also Table 3).

When the WTO took up its work on January 1, 1995 a new era started for trade between Developed and Developing Countries. By signing the Marrakesh agreement of the Uruguay Round of GATT a General Agreement on Trade in Services (GATS) was established for the first time. The provision of GATS (Mode 4) allows temporary labour mobility for the purpose of service delivery.

Six of the Pacific Island countries (Fiji, PNG, Samoa, Solomon Islands, Tonga, and Vanuatu) are members of the World Trade Organization (WTO) and covered by its principles and agreements. The only Asian country amongst the Pacific ACP members, Timor Leste, hopes that becoming a member of ASEAN will help to boost economic progress and make labour movement to and from this young Asian country easier when skilled labour mobility within the ASEAN Economic Community is expected to become a reality by 2015 when the Asian Economic Community (AEC) is established (Ibrahim 2007).

The WTO undertook much effort to regulate preferential trade agreements that before the establishment of the WTO had favoured some countries and disadvantaged others. Pacific Island countries enjoyed preferential trade with the European Union through the various Lomé Conventions (Grynberg 1998). With the Cotonou Agreement of 2000 a phasing out of preferential trade started which was to be concluded through Economic Partnership Agreements (EPAs) between the EU and ACP member states at the latest by the end of 2007 (Rampa 2007).

To become conform with WTO rules these EPAs need to cover substantially all the trade between the partners (Scollay and Grynberg 2005). While trade under the Lomé Conventions the EU granted duty-free access of certain goods from ACP countries to the EU market the EPAs now require ACP countries to follow the principle of reciprocity in trade, which means that goods produced in the EU enjoy duty-free / dutyreduced access to the markets of ACP countries (Kimunguyi 2005). Trade between the Least Developed Countries (LDCs) within the ACP and the EU can continue to be non-reciprocal under the Everything but Arms (EBA) initiative. For the Pacific Island countries this includes Kiribati, Samoa, Solomon Islands, Timor Leste, Tuvalu, and Vanuatu (EU 2013).

Negotiations are under way with the European Union for comprehensive Economic Partnership Agreement (EPA) with Pacific ACP countries (Kelsey 2007). Fiji and Papua New Guinea have already interim EPAs which were signed in 2009 and ratified in early 2011 (EU 2014). Overall the progress in achieving a comprehensive EPA of all Pacific ACP countries $^{\mathrm{c}}$ has been slow and burdensome. In December 2013 Fiji withdrew from the Pacific ACP trade talks organised by the Forum Secretariat maintaining the need to hold a regional meeting first without the EU's presence or pressure from the Forum Secretariat.

Developing countries also have preferential market access under various Generalized System of Preferences (GSP) (e.g. the EU, USA, Australia, and New Zealand have such 


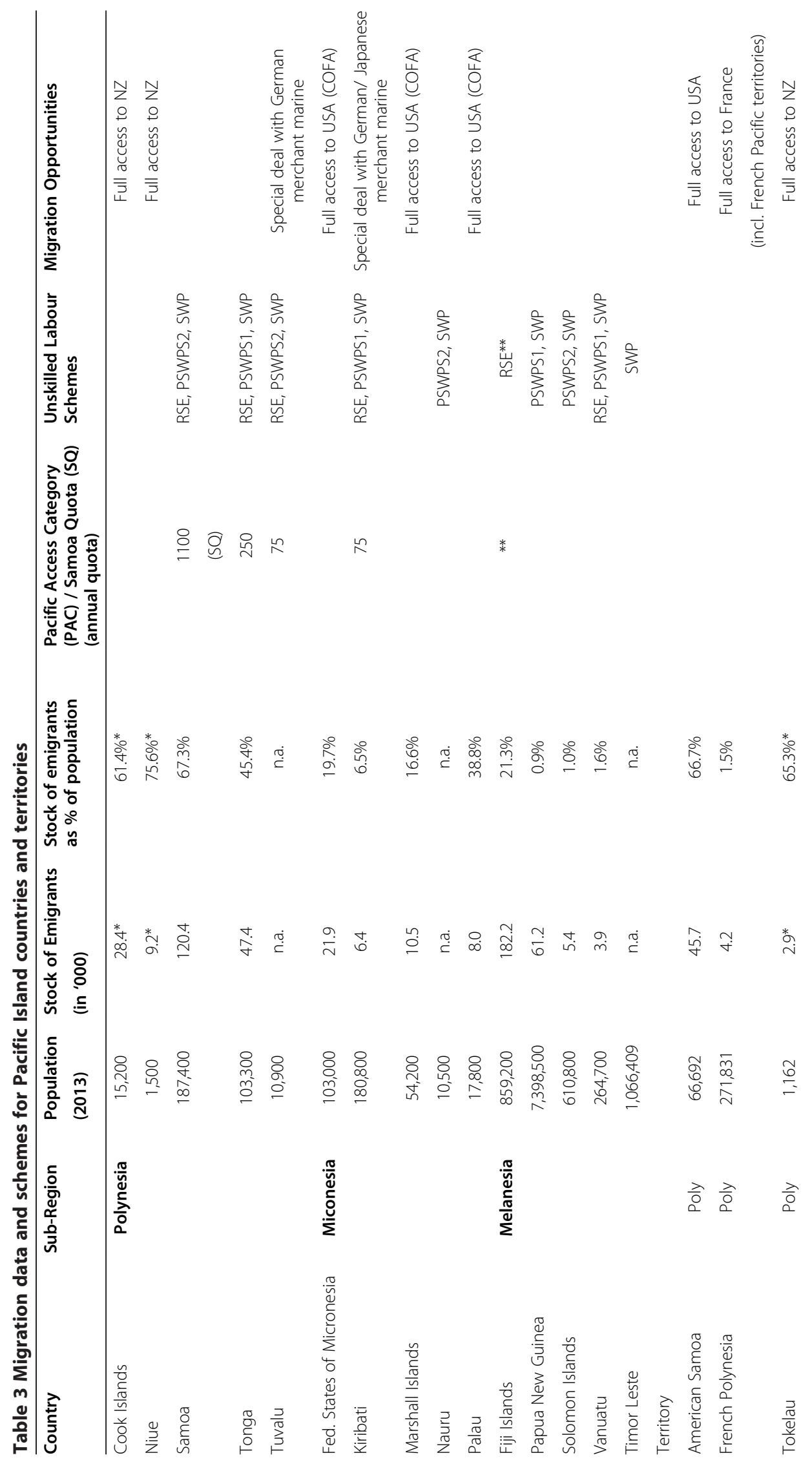




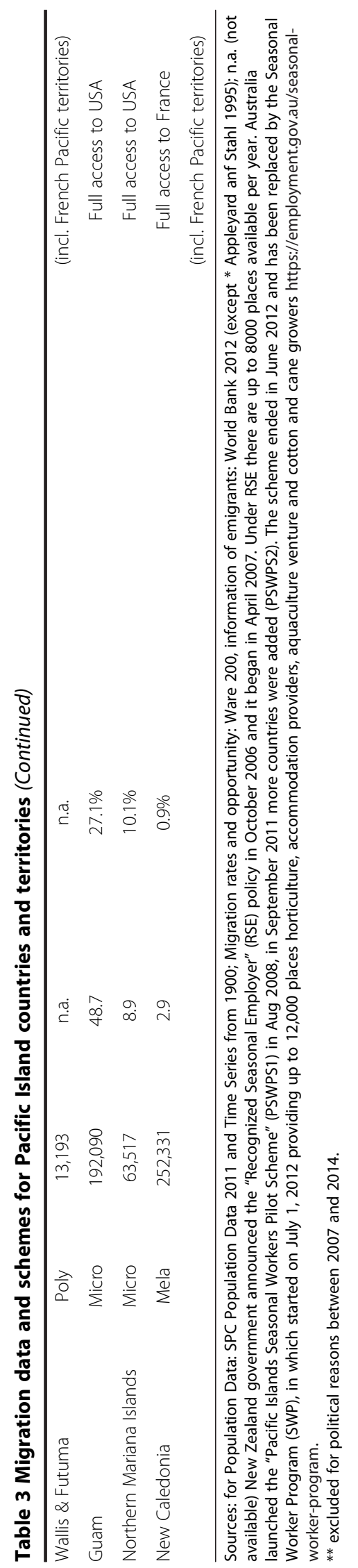


systems) that allow preferential market access, e.g. reduced tariff rates for goods from developing countries (Herz and Wagner 2011). The EU has been revising its GSP, excluding a number of countries that earlier had been covered (e.g. Fiji and PNG, which now fall under Economic Partnership Agreement Market Access Regulations, EU 2013). From the Pacific Island countries Cook Islands, Marshall Islands, Federated States of Micronesia, Nauru, Niue, and Tonga have market access to the EU through the GSP (EU 2013). The EU also has introduced a GSP + facility, which provides additional preferences to countries which ratify and implement 27 international conventions on core human and labour rights, the environment and good governance (Verma and Elman 2007, Switzer 2008). None of the 15 Pacific ACP countries at the moment qualifies for GSP + preferential market access to the EU (EU 2013a).

Pacific Island countries have negotiated (and are right now negotiating) a variety bilateral, regional and international trade agreements. The oldest of these agreements is the South Pacific Regional Trade and Economic Cooperation Agreement (SPARTECA), which started in 1981 and granted Forum Island countries preferential (non-reciprocal) access to Australia and New Zealand for a specified selection of goods originating from FICs (Gold and Thakur 1982, Rolfe 2007). The Pacific Island Countries Trade Agreement (PICTA) between Forum Island countries (except Australia and New Zealand) entered into force in 2003. In 2012 a Trade in Services agreement was added to PICTA (PICTA TIS), which also has the provision of a Temporary Movement of Natural Persons (TMNP) protocol (Mahadevan and Asafu-Adjaye, 2013). The TMNP protocol however is not yet open to signature.

Another regional trade agreement is the Melanesian Spearhead Group (MSG) Trade Agreement between Papua New Guinea (PNG), Solomon Islands, Vanuatu and Fiji), which started in 1993. In 2012 the MSG also introduced a Skills Movement Scheme (SMS) (MSG 2012).

At international levels agreements include the Pacific Agreement on Closer Economic Relations (PACER), which includes the Pacific Island countries, Australia and New Zealand (Gathii 2011, Kelsey 2006). PACER actually was not designed as a Free Trade Agreement, but as a safety valve for Australia and New Zealand for the case that any Forum Island Country (FIC) commences negotiations on Free Trade Agreements with other developed countries (e.g. with the EU). Such negotiations then was to trigger the need for consultations with Australia and New Zealand and negotiations for a Free Trade Agreement between those FICs who commenced negotiations for free trade agreements with other developed countries and Australia and New Zealand (Gathii 2011, Gupta 2008). Besides this PACER stipulated that negotiations between the FICs and Australia and New Zealand for a Free Trade Agreement needed to start not more than eight years after PICTA came into force (Kelsey 2004). Negotiations for PACERPlus, the proposed free trade agreement between the Forum Island Countries and Australia and New Zealand, were launched at the Pacific Islands Forum Leaders meeting in August 2009 (PIFS 2009).

In all the agreements that are currently under negotiation Pacific Island countries are eager to include regulations about labour mobility (GATS Mode 4 and beyond). Under PACER-Plus they hope that uni-laterally established (un-skilled) temporary labour mobility schemes by Australia and New Zealand can be made more sustainable and binding, if PACER-Plus includes aspects of temporary labour mobility. Chances seem to be 
slim that this can be achieved. There is little indication that new and binding access to Australian and New Zealand labour markets will result from the talks - a prospect that would leave many island nations without a key incentive to remain at the negotiating table (Morgan 2012; PIFS 2009).

In the 2010 and 2011 annual reports of the Office of the Chief Trade Adviser (OCTA) Regional Labour Mobility (beyond Mode 4) is listed as a priority agreed by Forum Trade Ministers in October 2009. On its website OCTA stresses that for many FICs, regional labour mobility (beyond Mode 4) is the key, if not the most important, issue in PACER Plus negotiations. Many Pacific Island Countries think that PACER Plus will not lead to mutually beneficial and development enhancing economic integration unless it results in greater integration of labour markets in the region. Australia has recognised the importance of labour mobility, but maintains it is a complex area of negotiations (http://www.octapic.org/pacer-plus-nearing-conclusion-says-chief-trade-adviser/). Pacific leaders also hope that PACER-Plus increases labour mobility between Island countries (Fiji Times, 17 March 2013).

Pacific ACP countries made a similar experience in the negotiations for EPAs (or a comprehensive EPA between the EU and Pacific ACP countries). The PACPS are targeting an annual quota of 10,000 semi-skilled and intermediate trainees (IT) from the PACPS to work in EU member countries under the EPA (PANG 2007). The EU is very hesitant to include the mobility of temporary labour in the EPA negotiations (Manservisi and Falkenberg 2006; Rampa 2007).

\section{Analysis of skilled and unskilled labour mobility from Pacific Island countries}

Faist and Fauser (2011) highlight important changes in migration paradigms: they notice the desirability of temporary labour migration based on the expectation that temporary migrants will constitute no loss in human capital and furthermore transmit a higher percentage of their income than permanent immigrants. Such temporary labour migration can also help to spread the benefits of migration widely and create familiarities with destination countries. Temporary labour migration can help Pacific Islanders acquire skills, knowledge and insights that can become crucial when they later have to leave their home countries for good.

Stahl and Appleyard (2007) hint at the development aspects of programmes by New Zealand and Australia to grant permanent access to people from Pacific Island countries for work purposes. New Zealand has granted citizenship to the people of the Cook Islands, Niue and Tokelau. The country also has a quota for Samoan citizen under which 1,100 Samoan nationals annually can become permanent residents. This Samoan quota exists since 1970. The Pacific Access Category (PAC) of 2002 allows 250 persons from Fiji ${ }^{\mathrm{d}}, 250$ from Tonga, 75 from Kiribati and 75 from Tuvalu to become permanent citizens. Under the SQ and PAC people from Pacific Island countries, who would not qualify under the general programs for skilled immigrants as their skills levels are often too low can enter New Zealand (see also Table 3).

Australia and New Zealand have also bilateral agreements with a number of Pacific Island countries in the area of seasonal migration of unskilled labour, such as the Recognised Seasonal Employer (RSE) policy New Zealand introduced in 2007 and a similar scheme Australia launched a year later. Such schemes had existed in the late 1960s for Fijian, Tongan and Samoans to work mainly in agriculture and forestry until 
the first coup in Fiji (1987) brought the scheme to an end (Lee 2009:10). Under the RSE policy, at present, up to 8,000 persons from (in order of absolute importance) Vanuatu, Tonga, Samoa, the Solomon Islands, Tuvalu and Kiribati can come to New Zealand for seasonal agricultural work. The Australian scheme allows people from Papua New Guinea, Vanuatu, Kiribati, Tonga, Samoa, the Solomon Islands, Tuvalu, and (since 2012) Timor Leste to enter Australia for seasonal unskilled employment mainly in the agricultural sector. Other economic sectors showed interest in employing temporary workers from the Pacific such as the New Zealand dairy and meat processing industries.

In the extension of the Australian scheme in 2012 a three year trial for labour recruitment to the tourism industry has been announced. Cotton and sugar cane growers as well as fisheries have become part of this trial which provides 1,500 jobs. Gibson and McKenzie (2011) suggest that the New Zealand RSE can make a meaningful development contribution to Pacific Island nations. Walmsley et al. (2009) argue that Australia and New Zealand would gain considerably from increasing quotas, particularly on unskilled labour and also the Pacific Island economies gained a lot from sending unskilled labour to Australia and New Zealand.

Initiatives taken up by metropolitan countries or by Pacific Island countries on labour mobility are highly controversial. Some see in them a return to the nineteenth century when colonial labour trade was (mis)used to develop the Australian economy. Others see them as a way to bring development to Pacific Island countries. Opening Pacific Islands' economies even more to imports from Australia and other countries to the disadvantage of their own, rather fragile and vulnerable economies might be easier to bear when labour mobility becomes a binding part of trade agreements.

However, it is very unlikely that Australia or New Zealand will give away the right to regulate labour movements considering benefits and potential threats to their own economies.

Larger Pacific Island countries, in particular Fiji and Papua New Guinea, train big numbers of professionals and graduates year by year. Many leave, making their skills available to others. The skills movement scheme of the MSG tries to balance labour supply and demand within the four economies of the MSG group. However, such schemes can only be successful if a bigger number of skilled labourers that are willing and able to migrate chose to go to a Pacific Island country rather than migrate to a metropolitan country. To make this happen requires incentives-incentives in terms of attractive wages, working conditions and living qualities. It also requires the establishment of a Pacific identity, where it becomes a value in itself to live and work in a country that culturally is similar to where migrants come from.

Such considerations also become relevant when places for people need to be found that leave their homes because of climate change. It is now the time to equip people with skills that enable them to positively contribute to the societies that are supposed to receive them. It is equally important that there is a Pacific Island identity that sees it natural to help out and welcome those who need support, who need new homes.

\section{Environmentally-induced migration in the Pacific Islands}

Pacific Islands have figured prominently in discourses about environmentally induced migration. Sea-level rise, the increase in intensity of natural hazards, the destruction of 
coral reefs and many other aspects of climate change lead to changes in the environment. At the same time they are social events: they create spaces of consideration, of discourses, of fear and assumption about an unsure and an unknown future. This is, in particular, true for the fate of those who live in places that might be submerged some time in the future.

It is obvious that changes in environmental quality can make people leave their homes. Still the terminology "environmental refugees" is rejected by many. Legal frameworks about refugees don't accept environmental reasons when granting refugee status.

There is little doubt that Pacific Island countries are much exposed to the impacts of climate change. There is also little doubt that many Pacific Island countries have been a source region for big numbers of emigrants. The question is, if there are indications that climate change and migration in the Pacific have been related in the past and if for the future one can expect big numbers of people from Pacific Island countries who are driven away from their homes.

The search for well-being and security is the major reason why people migrate (Gasper 2011). Hau'ofa (1993) described the pre-colonial Pacific as a 'sea of islands' within which people moved freely and frequently, created social networks, traded and exchanged goods, and at times engaged in conflict and attempted to exert dominance over one another (cited in Lee 2009: 1). Mobility within the Pacific Islands region created pluralistic, multicultural, transnational societies that benefited much from the mixing of people.

Small Island States are amongst those countries that are most exposed to various impacts of climate change. They "have characteristics which make them especially vulnerable to the effects of climate change, sea-level rise and extreme events" (IPCC, 2007: 15; IPCC 2012: 184). Their high vulnerability is intensified by low adaptation capacities and capabilities.

The main climate change challenges in the Pacific Islands are flooding, tropical storms (cyclones and hurricanes) and drought. Sea-level rise as a slow inset, low intensity hazard can make whole atoll island states disappear. Such hazards and risks, environmental, economic and social, and climate change and its impacts are major threats to development achievements (Asia-Pacific Disaster Report 2010). Within a few decades these island states could become uninhabitable and people have to move.

Campbell et al. (2010) have identified 86 cases of relocation in Pacific Islands between 1920 and 2000. 50 of them are related to environmental conditions. In the very near future resettlement most likely will increase tremendously. In February 2014 Fiji's President affirmed to the people of Kiribati "that you will not be refugees [...]. You will be able to migrate with dignity [...]. If the sea level continues to rise because the international community won't tackle global warming, some or all people of Kiribati may have to come and live in Fiji" (President Nailatikau quoted in Fiji Sun, Feb. 14, 2014).

End of May 2014 the Government of Kiribati purchased 5,460 acres of land on Vanua Levu, Fiji's second biggest island for AUS $\$ 9.3$ million (Fiji Broadcast Corporation, May $29^{\text {th }}$, 2014) ${ }^{\mathrm{e}}$. Although President Tong stressed that the land purchased is to strengthen Kiribati's food security, and not for relocation of I-Kiribati people, there are many who suggest that this was only done to contain the political impact of such move back home in Kiribati.

In Fiji a big number of relocation activities have already started. In January 2014 Fiji's Prime Minister announced that 676 communities have been identified that are threatened by sea-level rise generated by climate change; 42 of them shall be relocated within the next 10 years (Nailatikau 2014). 


\section{Of good and bad migrants}

People living in the Pacific Islands are not isolated from events elsewhere. Through media and their own experience they learn that there are different kinds of migrants, and that in not all of the cases migration brings the outcomes people hope for. There always have been asymmetries when it came to various forms of mobility.

Labour immigration is vital to many countries. Countries like Australia, New Zealand, Canada and the USA are built on migration, on 'good immigrants'. Refugees however are often perceived as 'bad migrants", as people who enter countries illegally, misuse social security and welfare provisions of these countries and threaten the well-being and even physical security of the law-abiding citizens of these countries. Often the public does not realise (or admit) that these people face prosecution, are displaced and depend on support from outside. It seems that the legal protection of refugees adds rigour to the attempt of countries to keep their borders tight and to prevent that such people even reach the territory of countries to seek the status of refugee. If they do so then there usually is a long process waiting for asylum seeker, which often deprive them of basic rights.

There is little reason to assume that this will be different when climate-change refugees from Pacific Islands are knocking on the doors of their powerful neighbours.

In the Pacific in particular Australia has become an example of relentless refugee policies which many see as a violation of the relevant conventions for refugees and human rights. People living in countries that soon might disappear from the world map are frightened that then they will be exposed to inhumane treatment like today asylum seeker in Australian detention centres in Papua New Guinea and Nauru: locked away for indefinite time, with few rights and even less opportunities to decide over their lives. Keeping this in mind it looks sarcastic that life-styles like those in Australia seem to be the most important cause for climate change, for the misery many Pacific Islanders will suffer in a few decades from now despite having contributed nothing to it.

Knowing that in a few decades they might have to look for places where they can live Pacific Islanders are not eager to become environmental refugees, even if this would become legally possible. Leaders of Pacific Island countries emphasise again and again that they do not want their people to be seen as potential environmental refugees. Kiribati President Anote Tong, for example, does not leave any doubt that he is aware that a time might come when the 32 atolls of his country are no more unsuitable to provide a home to the people of Kiribati. President Tong has started to find alternatives for more than 100,000 people, but not as environmental refugees, but to allow them to 'migrate in dignity'.

Considering the hostile attitude towards refugees it seems prudent to work towards solutions within Pacific Islands that enhances South-South cooperation and solidarity and resists to new dependencies towards former colonial masters. Metropolitan powers however have a role to play: they should meet their obligations in helping Pacific Island countries to generate capacities so that people can contribute to the societies of the countries receiving them.

\section{Conclusion}

Pacific Islanders have been mobile since people started settling in this part of the world. They always contributed to the betterment of societies they received tham. The near future will show, if a new stage of migration becomes dominant: the migration of people 
who have to leave their homes because of climate change. If this becomes reality then much has to be learnt from historical examples of migration, in particular those, where asymmetries of power resulted in dependencies and exploitation as a result of migration. To make people climate change refugees will compromise their right to live in dignity. All over the world migrants who can contribute to the societies of destination countries are less endangered to become socially isolated and not welcome.

The challenge is best taken up amongst the Pacific Island countries. Solidarity based on similar histories and cultural traits should make this easier to happen. Many Pacific Island countries already have meaningful populations of other Pacific Island countries. Challenges arising from climate and environmental change have the potential to strengthen Pacific Island identity and can show that the people in the Pacific Islands are able to master these challenges. Still financial support from metropolitan countries will be required to strengthen capacities in the Pacific Islands. Such support should not create new dependencies and increase existing ones, but should be based on the responsibilities the countries at the Pacific Rim have as the contributed to the challenge of climate change through their degree of industrialization and unsustainable lifestyles as major sources of emissions of greenhouse gases.

Today we do not even know the number of (additional) migrants because of climate change. In the face of slow environmental change, those who are able to move-those with money, social networks and alternative livelihoods-may migrate independently. The vulnerable poor, those with no capacity to move when environments deteriorate, the young and elderly may be left behind or forced to resettle later (Warner and Laczko 2008: 60). These then will become climate-change refugees: with few capacities and skills, little wanted by countries that should receive them, dependent on support and benevolence, and endangered to become a pawn in political in-fighting.

There is even the possibility of people being left behind in adverse environments. Such fear is not baseless: the majority of people in the so-called developed world bother little when people (already now) are living under extremely adverse environmental and/ or social conditions. Evacuating (Kelman 2008) sinking islands in the Pacific most likely will not happen. It is more likely that the last plane and ship leaves Kiribati (or Tuvalu) and people are still there, not forgotten, but never intended to be brought to safety, neither socially nor environmentally.

\section{Endnotes}

${ }^{a}$ The term Pacific Islands countries in the context of this paper refers to 15 Pacific ACP states; 14 of them are organized in the Pacific Island Forum Secretariat (PIFS) plus Timor Leste, an island state that is geographically situated in Asia.

${ }^{\mathrm{b}}$ Throughout the paper the modern names of island countries and territories are used.

'Timor Leste is not included in the Economic Partnership Agreement, but it has an observer status and most likely would be able to join once the agreement is ready to be signed.

dFiji joined the scheme in 2003, and after the coup of 2006, Fijis participation in the scheme discontinued.

${ }^{\mathrm{e}} 5,460$ acres $\left(22.1 \mathrm{~km}^{2}\right)$ is considerably bigger than South Tarawa $\left(15.76 \mathrm{~km}^{2}\right)$ where almost half of Kiribati's population is living. 


\section{Competing interests}

The author declares that he has no competing interests.

Received: 7 November 2014 Accepted: 10 November 2014 Published online: 05 February 2015

\section{References}

ACP-Observatory on Migration. 2012. Assessment of South-South Labour Mobility in the Pacific region, Terms of Reference for the call for tenders for undertaking research commissioned by the ACP Observatory on Migration. Brussels: ACP Observatory on Migration.

ADB (Asian Development Bank. 2008. Skilling the Pacific. Technical and Vocational Education and Training in the Pacific. Asian Development Bank: Manila.

Asia-Pacific Disaster Report. 2010. Protecting Development Gains, Reducing Disaster Vulnerability and Building Resilience in Asia and the Pacific. Bangkok, Thailand: ESCAP / UNISDR.

Booth, Heather, Guangyu Zhang, Maheshra Rao, Fakavae Taomia, and Ron Duncan. 2006. Population pressures in Papua New Guinea, the Pacific Island Economies, and Timor Leste. Working Papers in Demography No. 102, Research School of Social Sciences, Canberra: The Australian National University.

Campbell, John R. 2014. Climate-Change Migration in the Pacific. The Contemporary Pacific 26(1): 1-28.

Campbell, John R, and Richard Bedford. 2014. Migration and Climate Change in Oceania. In People on the Move in a Changing Climate. The Regional Impact of Environmental Change on Migration, ed. E Piguet and F Laczko. Dordrecht Heidelberg New York London: Springer.

Campbell, John R, Michael Goldsmith, and Kanyathu Koshy. 2010. Community Relocation as an option for adaptation to the effects of climate change and climate variability in Pacific Island Countries (PICS). Final report for APN project 2005-14-NSY-Campbell. Hamilton: University of Waikato.

Chand, Satish. 2006. Working Paper 06-08. Crawford School of Economics and Government, Canberra: The Australian National University. Economic growth in Forum Island countries: lessons of the past decade and opportunities ahead.

Duncan, Ron, and Carmen Voigt-Graf. 2008. Labour market scenarios for the Asian Decent Work Decade in the Pacific Island countries. International Labour Organisation Asia-Pacific Working Paper Series. Manila: ILO Regional Office for Asia and the Pacific.

EU 2014. Overview of EPA negotiations. Updated 7 February 2014. Available from http://trade.ec.europa.eu/doclib/ docs/2009/september/tradoc_144912.pdf.

EU 2013. Revised EU trade scheme to help developing countries applies on 1 January 2014. Press Release, December 19. Available from http://europa.eu/rapid/press-release_MEMO-13-1187_en.htm?locale=FR.

EU 2013a. 10 countries to benefit from EU preferential trade scheme GSP + as of 1 January 2014. Press Release, December 30. Available from http://trade.ec.europa.eu/doclib/press/index.cfm?id=1006

Faist, Thomas, and Margit Fauser. 2011. The migration-development nexus: towards a transnational perspective. In The migration-development nexus: a transnational perspective, ed. Faist Thomas, Fauser Margit, and Kivisto Peter. Basingstroke: Palgrave Macmillan.

Firth, Stewart. 1978. German Labour Policy in Nauru and Angaur, 1906-1914. The Journal of Pacific History 13(1): 36-52.

Flanagan, Tracey, Meredith Wilkie, and Susanna Iuliano. 2003. Australian South Sea Islanders A century of race discrimination under Australian law. The role of South Sea Islanders in Australia's economic development Available from https://www.humanrights.gov.au/erace-archives-australian-south-sea-islanders

Gasper, Des. 2011. International migration, well-being and transnational ethics. In Transnational migration and human security, edited by Truong, T.-D. and Gasper, D. Heidelberg, Dordrecht, London, New York: Springer.

Gathii, James Thuo. 2011. The neoliberal turn in regional trade agreements. Washington Law Review 86(3): 421-474.

Gibson, John, and David McKenzie. 2011. Australia's Pacific Seasonal Worker Pilot Scheme (PSWPS): development impacts in the first two years. Department of Economics, Working Paper in Economics, 09/11. Hamilton: University of Waikato.

Gold, Hyam, and Ramesh Thakur. 1982. New Zealand and Australia: Free Trade Agreement Mark II. The World Today 38(10): 402-410

Goss, Jon, and Bruce Lindquist. 2000. Placing Movers: An Overview of the Asian-Pacific Migration System. The Contemporary Pacific 12(2): 385-414.

Grynberg, Roman. 1998. The WTO incompatibility of the Lomé trade provisions. Asia Pacific School of Economics and Management, Working Papers 98/3. Canberra: The Australian National University.

Gupta, Sayantan. 2008. Changing Faces of International Trade: Multilateralism to Regionalism. Journal of International Commercial Law and Technology 3(4): 260-273.

Hau'ofa, Epeli. 1993. A New Oceania: Rediscovery of our Sea of Islands. Suva, Fiji: University of the South Pacific

Herz, Bernhand, and Marco Wagner. 2011. The Dark Side of the Generalized System of Preferences. Review of International Economics 19(4): 763-775.

Hills, Howard Loomis. 1984. Compact of Free Association for Micronesia: Constitutional and International Law Issues. The International Lawyer 18: 583-608.

Ibrahim, Fatimah Wati. 2007. Assessing regional integration: The progress of ASEAN regional grouping. In: International Economic Conference on Trade and Industry (IECTI) 2007, 3-5 December 2007, Bayview Hotel Georgetown, Penang. Available from http://repo.uum.edu.my/2412/

Intergovernmental Panel on Climate Change (IPCC). 2007. In Climate Change 2007: Impacts, Adaptation and Vulnerability. Contribution of Working Group II to the Fourth Assessment Report of the Intergovernmental Panel on Climate Change, ed. Parry Paul, Canziani Osvaldo, Palutikof Jean, Paul van der Linden, and Hanson Clair. Cambridge, UK: Cambridge University Press.

Intergovernmental Panel on Climate Change (IPCC) 2012. Managing the Risks of Extreme Events and Disasters to Advance Climate Change Adaptation. A Special Report of Working Groups I and II of the Intergovernmental Panel on Climate Change [Field, C.B., V. Barros, T.F. Stocker, D. Qin, D.J. Dokken, K.L. Ebi, M.D. Mastrandrea, K.J. Mach, G.-K. 
Plattner, S.K. Allen, M. Tignor, and P.M. Midgley (eds.)]. Cambridge University Press, Cambridge, UK, and New York, NY, USA, $582 \mathrm{pp}$.

Jupp, James. 2007. From White Australia to Woomera. The story of Australian immigration, 2nd ed. Port Melbourne: Cambridge University Press.

Keitner, Chimene I, and W Michael Reisman. 2003. Free Association: The United States Experience. Texas International Law Journal 1(39): 1-63.

Kelman, Ilan. 2008. Island evacuation. Forced Migration Review, Issue 31: 20-21.

Kelsey, Jane. 2004. World trade and small nations in the South Pacific region. Kansas Journal of Law and Public Policy 14: 247-306.

Kelsey, Jane. 2006. Free trade agreements: boon or bane?: through the lens of PACER. Victoria University of Wellington Law Review 37: 391-419.

Kelsey, Jane. 2007. Going Nowhere in a Hurry? The Pacific's EPA Negotiations with the European Union. Victoria University of Wellington Law Review 38: 81-103.

Kimunguyi, Patrick. 2005. The European Union and Developing Countries the Challenges of Trade Liberalisation in the Contonou Process, Paper of Contemporary Europe Research Centre, University of Melbourne. Available from http://www.eusa-japan.org/download/eusa_ap/paper_PatrikKimunguyi.pdf.

Lee, Helen. 2009. Pacific Migration and Transnationalism: Historical Perspectives. In Migration and Transnationalism. Pacific Perspectives, ed. Lee Helen and Francis Steve Tupai. Canberra: ANU Press.

Mahadevan, Renuka, and John Asafu-Adjaye. 2013. Unilateral Liberalisation or Trade Agreements: Which Way Forward for the Pacific? The World Economy 36(10): 1355-1372.

Manservisi, Stefano, and Karl Falkenberg. 2006. Leaked letter from the EC's Falkenberg and Manservisi to Tavola on Pacific EPA Available from http://www.bilaterals.org/IMG/pdf/EC_Falkenberg_Manservisi_to_Tavola_Oct-06.pdf.

Matisoo-Smith, Elizabeth, and Judith Helen Robins. 2004. Origins and dispersals of Pacific peoples: Evidence from mtDNA phylogenies of the Pacific rat. Proceedings of the National Academy of Science USA 101 (24): 9167-9172.

Moore, Clive, Jacqueline Leckie, and Doug Munro (eds.). 1990. Labour in the South Pacific. Townsville, Qld: James Cook University of Northern Queensland.

Morgan, Wesley. 2012. Labour mobility through PACER-Plus? An unlikely prospect. Devpolicy Blog from the Development Policy Centre. Available from http://devpolicy.org/labour-mobility-through-pacer-plus-an-unlikely-prospect20120402/.

MSG (Melanesian Spearhead Group) 2012. MSG Skills Movement Scheme. Available from http://www.msgsec.info/index. php/msg-skills-movement-scheme

Munro, Doug. 1990. Origins of Labourers in the South Pacific: commentary and statistics. In Labour in the South Pacific, edited by Clive Moore, Jacqueline Leckie, and Doug Munro. Townsville, Qld: James Cook University of Northern Queensland.

Nailatikau, Ratu E. (2014). His Excellency Ratu Epeli Nailatikau- Address at a Function on His State Visit to Nauru. Available from http://updates7131.rssing.com/browser.php?indx=5440860\&item=61.

PANG (Pacific Network on Globalisation). 2007. Social Impact Assessment of the Economic Partnership Agreement (EPA) being negotiated between the European Community and the Pacific ACP states'. Report to the Pacific Islands Forum Secretariat. PANG: Suva.

PIFS (Pacific Islands Forum Secretariat) 2009. Fourteenth Pacific Islands Forum, Cairns, Australia, 5 - 6 August 2009, Forum Communiqué. Available from http://www.forumsec.org/resources/uploads/attachments/documents/2009\% 20Forum\%20Communique,\%20Cairns,\%20Australia\%205-6\%20Aug.pdf.

Rampa, Francesco. 2007. Implementation of Article 37(4) of the Cotonou Agreement. Provision of technical support to assist the Pacific ACP Region in the Review of EPA Negotiations. Draft Interim Report submitted to the Pacific Islands Forum Secretariat. Available from http://62.58.77.233/library/files/Rampa_EN_0107_ECDPM_Implementationof-article-37-4-of-the-Cotonou-agreement.pdf.

Ridgell, Reilly. 2006. Honolulu. Hawai'i: Bess Press. Pacific nations and territories: the islands of Micronesia, Melanesia, and Polynesia, 4th ed.

Rolfe, Jim. 2007. Many Small States, two regions, different constructions. Social and Economic Studies 56(1/2): 96-134

Scollay, Robert, and R Roman Grynberg. 2005. Substantially All Trade: Which Definitions are fulfilled in Practice? An Empirical Investigation. London: Commonwealth Secretariat.

Shineberg, Dorothy. 1967. They Came for Sandalwood: A Study of the Sandalwood Trade in the South-West Pacific, 1830-1865. Melbourne: Melbourne University Press.

Stahl, Charles W., and Reginald Appleyard. 2007. Migration and development in the Pacific Islands: lessons from the New Zealand Experience. Canberra: Australian Agency for International Development (AusAID).

Switzer, Stephanie. 2008. Environmental Protection and the Generalized System of Preferences: A Legal and Appropriate Linkage? The International and Comparative Law Quarterly 57(1): 113-147.

Verma, Anil, and Gail Elman. 2007. Labour Standards for a Fair Globalization for Workers of the World. The Good Society 16(2): 57-64.

Walmsley, Terrie, Syud Amer Ahmed, and Christopher Parsons. 2009. The impact of liberalizing labour mobility in the Pacific Region. GTAP Working Papers No. 31. West Lafayette: Centre for Global Trade Analysis, Purdue University.

Ward, RG. 1972. The Pacific Beche-de-mer Trade with Special Reference to Fiji. In Man in the Pacific: Essays on Geographical Change in the Pacific Islands, ed. RG Ward. Oxford: Clarendon.

Ward, RG. 1989. Earth's empty quarter? The Pacific Islands in a Pacific Century. The Geographical Journal 155(2): 235-246.

Warner, Koko, and Frank Laczko. 2008. A global research agenda. Climate change and displacement Forced Migration Review 31: 59-60.

World Bank. 2006. At Home and Away - Expanding job opportunities for Pacific Islanders through labour mobility. Washington, D.C.: The World Bank.

World Bank. 2011. Migration and remittances factbook 2011, 2nd ed. Washington, DC: World Bank. 